\title{
COMMUNICATIONS
}

\section{The Use of Polymer Supports in Organic Synthesis. The Synthesis of Monotrityl Ethers of Symmetrical Diols}

\author{
ClifFord C. LeZnOFF AND JACK Y. WONG \\ Department of Chemistry, York University, Downsuiew, Ontario
}

\begin{abstract}
A modified Merrifield polymer containing acid chloride groups was used in the selective synthesis of the monotrityl ethers of the symmetrical diols, $\mathrm{HO}-\left(\mathrm{CH}_{2}\right)_{n}-\mathrm{OH}$, where $n=2,4,6,8$, and 10 . This procedure constitutes a unique method of blocking one functional group of a completely symmetrical difunctional compound.

Une résine modifiée du type Merrifield comprenant des groupes chlorure d'acide, a été utilisée dans la synthèse sélective d'éthers monotritylés de diols symétriques $\mathrm{HO}-\left(\mathrm{CH}_{2}\right)_{n}-\mathrm{OH}$ avec $n=2,4,6,8$, et 10 . Ce procédé constitue une méthode unique pour bloquer un groupe fonctionnel dans un composé bifonctionnel complètement symétrique.

[Traduit par le journal]
\end{abstract}

The use of insoluble polymer supports in the synthesis of polypeptides (1), polynucleotides (2), and even polysaccharides (3) has been well documented. The unique potential of solid phase synthesis, however, has not generally been applied to organic synthetic problems. The synthesis of a threaded carbocycle by Harrison and Harrison (4), hydrogenation on polymer supported catalysts (5), polymer supported Wittig reagents (6), and the base condensation of mixed esters $(7,8)$, are, however, some of the few attempts to use insoluble polymer supports to solve specific synthetic problems.

The concept of using blocking groups in organic synthesis is well established. For example, the use of trityl chloride in specifically blocking only the 5 -hydroxyl group of deoxyribonucleosides is well known (9), but this procedure depends on the fact that the $5^{\prime}$ hydroxyl group is a primary alcohol and hence reacts much faster than the 3 -hydroxy group which is a secondary alcohol. It is this difference in the nature of the alcohol groups that allows selective blocking to occur. In this communication, we propose a general method whereby one can selectively block one alcohol group of a completely symmetrical diol.

The selective blocking of one functional group of a completely symmetrical difunctional compound can be accomplished using functionalized insoluble polymer containing acid chloride available Merrifield resin ( $2 \%$ cross-linked polystyrene beads with $1.7 \mathrm{mmol}$ of $-\mathrm{CH}_{2} \mathrm{Cl}$ groups per gram of resin, obtained from Schwarz/ Mann) was modified, according to the procedure of Kusama and Hayatsu (10), to an insoluble polymer containing acid chloride groups, (D- $-\mathrm{C}_{6} \mathrm{H}_{4}-\mathrm{CH}_{2} \mathrm{COCl}$ (1). The acid chloride 1 contained 0.8 mequiv $\mathrm{Cl}^{1} / \mathrm{g}$ of polymer as determined by the modified Vollhard procedure (11). Polymer 1 contains only one in six functionalized phenyl groups along the polymer chain and hence the acid chloride polymer 1 acts as a dilute reagent.

In a typical experiment, $4.2 \mathrm{~g}$ of resin 1 and $4.0 \mathrm{~g}$ of 1,4 -butanediol $(2 b)$ in $40 \mathrm{ml}$ of pyridine were stirred for $48 \mathrm{~h}$ at room temperature and for $24 \mathrm{~h}$ at $105^{\circ} \mathrm{C}$, to yield a resin ester $(3 b)$ in which the diol is attached to the polymer by only one of the alcohol moieties. ${ }^{1}$ The use of the insoluble polymer support allows one to use a large excess of diol, the excess of which can be recovered, after reaction has occurred, by simple filtration of the polymer. The quantity

\footnotetext{
'The possibility exists that two adjacent phenyl rings are functionalized and hence both ends of the symmetrical diol (2b) could attach themselves to the polymer. Although Kraus and Patchornik have demonstrated that this in fact can happen (7), the use of a large excess of diol greatly diminishes the chance of this occurring.
} 


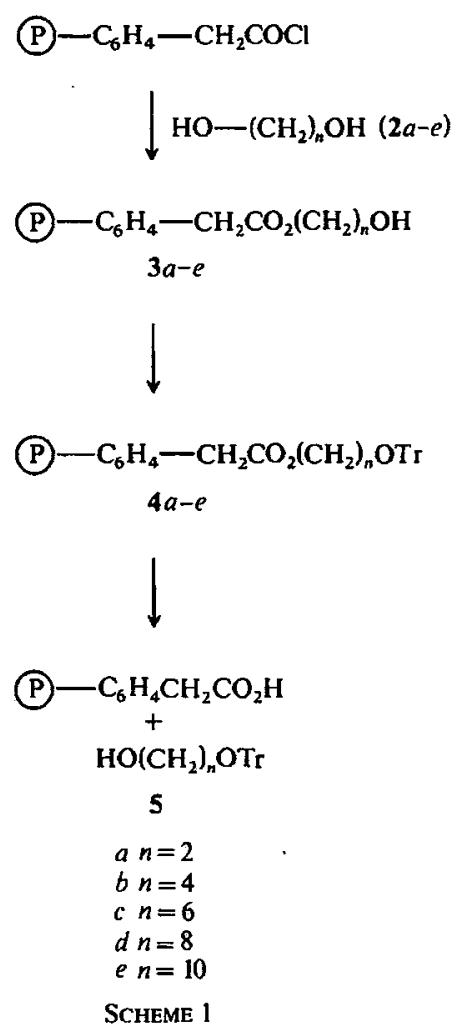

of diol $2 b$ attached to the polymer was determined by hydrolysis of $4.7 \mathrm{~g}$ of resin $3 b$ with $20 \mathrm{ml}$ of a 1:1 mixture of dioxane and concentrated ammonia for $94 \mathrm{~h}$. The recovery of $78.5 \mathrm{mg}$ of diol $2 b$ showed that the polymer 1 has a capacity of being charged with $0.20 \mathrm{mmol}$ of $2 b$ per gram.

Reaction of resin ester $3 b$ with trityl chloride in pyridine $(9,12)$ gave the resin trityl ether (4b). Hydrolysis of $3.71 \mathrm{~g}$ of $4 b$ as described above and purification on t.l.c. gave $90 \mathrm{mg}$ of 1-O-trityl-1,4-butanediol $(5 b)$ in $37 \%$ yield based on amount of diol charged on the polymer. The properties and yields of a series of 1-O-trityl$1, n$-alkanediols, synthesized by the polymer support method are listed in Table 1. Hydrolysis of $5 a-e$ with $80 \%$ acetic acid led to quantitative recovery of trityl alcohol and starting diols $2 a-e(9)$.

As shown in Table 1, only the monotrityl ether of ethylene glycol ( $2 a$ ) had been previously prepared by classical methods (12). It is interesting to note that the yield of compound $2 a$
TABle 1. Physical data of 1- $O$-trityl-1,n-alkanediols

\begin{tabular}{lccc}
\hline \hline Compound & $\begin{array}{c}\text { M.p. } \\
\left({ }^{\circ} \mathrm{C}\right)\end{array}$ & $\begin{array}{c}\text { Yield } \\
\text { (mmol/g polymer) }\end{array}$ & $\begin{array}{c}\text { Yield } \\
(\%)\end{array}$ \\
\hline TrO $\left(\mathrm{CH}_{2}\right)_{2} \mathrm{OH}$ & $95-96 \ddagger$ & 0.087 & 44 \\
$\mathrm{TrO}\left(\mathrm{CH}_{2}\right)_{4} \mathrm{OH}$ & $65-67$ & 0.074 & 37 \\
TrO $\left(\mathrm{CH}_{2}\right)_{6} \mathrm{OH}$ & $68-69$ & 0.085 & 47 \\
TrO $\left(\mathrm{CH}_{2}\right)_{8} \mathrm{OH}$ & oil & 0.072 & 51 \\
TrO $\left(\mathrm{CH}_{2}\right)_{10} \mathrm{OH}$ & oil & 0.048 & 51 \\
\hline
\end{tabular}

*All compounds showed sa tisfactory elemental analyses. †Based on amount of diol released from the polymer on base hydrolysis.

fLiterature $98-100^{\circ}$ (12).

was not recorded (12). Our own attempts to prepare the monotrityl ether of 1,10-decanediol (5e) by classical methods (12) gave a mixture of four compounds, $2 e$, $5 e$, di-O-trityl-1,10decanediol, and trityl alcohol, which proved difficult to separate even by preparative t.l.c.

The modification of one functional group of symmetrical difunctional compounds by the use of insoluble polymer supports will be further explored.

We thank the National Research Council of Canada for a grant in aid of this research.

1. R. B. Merrifield. J. Am. Chem. Soc. 85, 2149 (1963); R. B. Merrifield. Sci. 150, 178 (1965)

2. R. L. Letsinger and V. Mahadevan. J. Am. Chem. Soc. 88, 5319 (1966).

3. J. M. Frechet and C. Schuerch. J. Am. Chem. Soc. 93, 492 (1971).

4. I. T. Harrison and S. Harrison. J. Am. Chem. Soc. 89, 5724 (1967).

5. R. H. Grubss and LeRoy C. Kroll. J. Am. Chem. Soc. 93, 3063 (1971); R. L. LAZCANOT and J. E. Germain. Bull. Chim. Soc. Fr. 1869 (1971)

6. F. Camps, J. Castells, J. Font, and F. Vela. Tetrahedron Lett. 1715 (1971); S. V. MCKINLEY and J. W. Rakshys Jr. Chem. Commun. 134 (1972).

7. M. A. Kraus and A. Patchornik. J. Am. Chem. Soc. 93, 7325 (1971).

8. J. I. Crowley and H. Rapoport, J. Am. Chem. Soc. 92, $6363(1970)$.

9. A. M. MiCheLson and A. R. TODD. J. Chem. Soc. 951 (1953); G. Weimann and H. G. Khorana. J. Am. Chem. Soc. 84, 419 (1962).

10. T. Kusama and H. Hayatsu. Chem. Pharm. Bull. 18, $319(1970)$

11. J. M. Stewart and J. D. Young. Solid phase peptide synthesis. W. H. Freeman, San Francisco. 1969. p. 27; P. B. HaWK, B. L. OSER, and W. H. SUMMERSON. Practical physiological chemistry. 13th ed. Blakiston, 1954. p. 955.

12. B. Helferich, P. E. Speidel, and W. Toeldte. Chem. Ber. 56, 769 (1923). 